\title{
Music Lexicographer Jiří Fukač and the Brno School of Music Lexicography
}

\author{
Petr Macek / macek@phil.muni.cz \\ Department of Musicology, Faculty of Arts, Masaryk University, Brno, CZ
}

\begin{abstract}
The study summarizes the activity in the field of music lexicography of Jiři Fukač (1936-2002), professor of musicology at the Brno-based Masaryk University, who successfully resumed the activities of the Brno School of Music Lexicography, constituted chiefly by efforts of Gracian Černušák, Vladimír Helfert and Bohumír Štědroň.

Already as a student Fukač collaborated as both author and organizer on the two-volume Československý hudebni slovník osob a institucí (Czechoslovak Music Dictionary of Persons and Institutions, 1963, 1965). In 1966 he and Jiři Vysloužil initiated foundation of Kabinet hudební lexikografie (Office of Music Lexicography) and preparations for the new subject-focused dictionary project, later called Slovník české hudební kultury (Dictionary of Czech Music Culture) started. Fukač's contribution was crucial and it was his tireless effort including writing texts of individual entries, editing texts by others and effecting his organizational skills, that finally lead to the successful completion of the project in 1997. The result undoubtedly presents a fundament in Czech music lexicography in both conception and extent.

Then Jiři Fukač started to work on further projects of music lexicography: he actively participated in preparations and realization of the big lexicographical project of the Sudeten German Music Institute in Regensburg titled Lexikon zur deutschen Musikkultur (Böhmen, Mähren, Sudetenschlesien) published in Munich in 2000, where he was member of the scholarly board of the project and contributed to the conceptual and methodological preparations. In 2000 Fukač together with Petr Macek and Mikuláš Bek started preparations for the new web-based project of the Czech Music Dictionary of Persons and Institutions. A fatal illness didn't allow him to proceed further.
\end{abstract}

\section{Keywords}

Jiří Fukač, Brno, Czech musicology, music, lexicography 
An important core of Fukač's scholarly musicological output for a considerable part of his life was the sequel to activities of the Brno School of Music Lexicography that had been constituted by efforts of Gracian Černušák, Vladimír Helfert and Bohumír Štědroň. It was professor Štědroň as his university teacher and one of three scholarly editors of the prestige project of Československý hudebni slovnik osob a instituci (Czechoslovak Music Dictionary of Persons and Institutions) that had been developed from the 1950s at the Brno university musicological department, who aroused Fukač's interest in music lexicography. Already as a student Fukač collaborated on preparations of this project under Štědroň's supervision, especially as organizer, partly as author, and he acquired experience for his own work in the field of music lexicography. On his own he elaborated the entry of his uncle doc. Karel Urbánek, a choirmaster and teacher of music. Under the acronym J. Fč. he also published appendices to several entries, especially composers included in the so called Collection of the Knights of the Cross (Křižovnická sbírka), e. g. Václav Pražák, František Ludvík Poppe, Jan Adam Lavetius, František Josef Dollhof, but also from the later history, e. g. the composer Josef Berg or the music journalist Jaroslav Procházka. For Fukač this co-operation was undoubtedly most important for the methodological and organizational experience with such an extensive dictionary project.

The Czechoslovak Music Dictionary of Persons and Institutions ( $\check{C} S H S$ ) represented a project of extraordinary significance, nearly 11.000 entries gave accuracy to the picture of history of Czech and Slovak music culture and lead to a better approach of experts from abroad to this territory. Preparations and edition of the work, however, lead to several problems. Especially the name entries incorporated and dispersed a vast amount of chronological, topographic, heuristic and bibliographical information. Absence of a subject explanatory viewpoint was gradually becoming a serious deficiency. Call for complementing the dictionary by a systematic subject-focused lexicographical work was becoming more urgent as new music encyclopaedias were published abroad that summarized the present state of the post-war research including Czech or rather Czechoslovak themes but not the way that would satisfy the inland expert public. They felt the need that the image of the local music culture gets significantly appended, corrected factually and explained from the local point of view. The reaction to the state of knowledge of our music abroad should have been the elaboration of a new music dictionary that would reflect the local themes in the form of a subject dictionary on the level comparable with the mentioned foreign works. The new dictionary should also have represented a pendant to new synthetic historical treatises on music. In the 1960s several opuses of this kind were already worked on: the two-volume History of Czech Music Culture 1890/1945, published 1972-1981, the music volume of the Československá vlastivěda published in 1971, and also two volumes of the History of Czech Theatre, relevant for music.

Discussion on further tasks and goals of the local music lexicography started immediately after the publication of ČSHS in the musicological section of the then Union of Czechoslovak Composers and investigated the possibilities of an updated re-edition. The 
musicological department at the Brno university, where the complete documentation was deposited and where Bohumír Štědroň carried on assembling material for the intended re-edition, founded the Kabinet hudebni lexikografie (Office of Music Lexicography) in 1966 on the initiative of Jiří Vysloužil and Jiří Fukač. The then Institute of Musicology of the Czech Academy of Sciences supported this effort by hiring Štědroň's pupil Radovan Cígler to process the overall modern history and methodological problems of the Czech music lexicography (1967). Jiří Vysloužil as head and Jiří Fukač as secretary of the Office informed the public about their work in the article Nárys dokumentačního zajištěni základnich úkolu československé hudebni lexikografie (Outline of the documentary base for the fundamental tasks of the Czechoslovak music lexicography), published in Hudebni věda 5/1968. The Office contacted Hans Heinrich Eggebrecht, editor of the subject volume of the new edition of the Riemann Musiklexikon. On 1 October 1969 the Office organized an international meeting of music lexicographers as a part of the 4th International Music Festival in Brno. The participants included Hans Heinrich Eggebrecht, Harald Heckmann, Bohumír Štědron, Jiří Sehnal, Tomislav Volek and others. Here Jiří Vysloužil and Jiří Fukač for the first time published the conception of a new Czech music dictionary. This proposal was published together with the proceedings of the international meeting in the musicological volume of the Sbornik pracífilosofické fakulty brněnské university (Anthology of texts of the Faculty of Arts of the Brno university), series H, No. 6 in 1971, and the whole volume was dedicated to the history and methods of music lexicography. Fukač himself published an expert study here with the title Hudebnělexikografická metoda Bohumíra Jana Dlabače a jeji uměleckohistorické pozadi (Musicolexicographic Method of Bohumír Jan Dlabač and its Artistic and Historical Background).

The next meeting took place 10 years later exactly, on 1 October 1979 , as part of the 14th International Music Festival in Brno. The protocol, compiled by Miloš Štědroň, was published in the above mentioned Sbornik, series H, No. 16 in 1981. Thanks to these and other meetings the work of the Office was constantly confronted with several experts from abroad. Between 1970-1974 the Office published a series for its collaborators $M a$ teriály kabinetu pro hudebni lexikografii (Materials of the Office of Music Lexicography). Its penultimate, fifth volume of 1973 contained the complete proposal of glossary of the new work that should have been called Český hudebni slovnik (Czech Music Dictionary).

In 1967-1977 there were scholarly and some other external reasons that were changing the idea of the work that should follow ČSHS in a new quality. As soon as 1969 the plan to solve the Czech and Slovak problems together was abandoned. The rules of co-operation used for the ČSHS now proved ineffective and inapplicable for the subject-focused part: before the Czech and Slovak music lexicographers (e. g. Zdenko Nováček, Laco Mokrý, Richard Rybarič, Ernest Zavarský) agreed to work separately. The conception of 1969 until mid-1970s presumed a joint explanation of phenomena of both persons and subjects. The glossary proposal of 1973 presented some 800 entries of music terms, concepts and facts of distinctively „Czech“ specificity and about 2850 further entries on major persons and institutional phenomena. 
However, the consultations with the publisher Supraphon revealed that a purely subject-focused dictionary has to be done. The editors Jiří Vysloužil and Jiří Fukač, appointed upon the agreement with Supraphon, had to change the plan and proportions of the work-in-progress. The conception now resembled the model of the subject-focused volume of the Riemann Musiklexikon that represented an ideal scholarly music dictionary of this kind as for coherence, interpretative explanatory method and extent. The number of subject entries now almost doubled, and as the immediate succession to the $\check{C}$ SHS was dropped, also the title Český hudebni slownik (Czech Music Dictionary) was abandoned in favour of the new title Slovnik české hudebni kultury (Dictionary of Czech Music Culture, SČHK).

The Office of Music Lexicography gradually massed a team whose core consisted of musicologists of the Brno university musicological department (Faculty of Arts) and other experts from both Prague and Brno. With the support of the Czech Musical Fund the new bibliographic and factographic documentation was conceived and several test and model entries were written. The work on the final texts could be launched as late as 1977 when the circle of authors of entries got stabilized.

The typewritten version of the final work was passed to Supraphon in 1988 and preparations for publication were launched immediately, especially the linguistic revision. After November 1989 there was a new possibility to supplement the text by information from the newly acquired Western and the once prohibited literature; some entries were formulated anew as the politically delicate problems of several previous decades could now be interpreted openly. At the same time, however, the complicated process of „denationalization" of Supraphon was launched and the publication became impossible for economic and organizational reasons. The task of finalizing the project was taken over by Bärenreiter Editio Supraphon Praha that established its dislocated department and attached it to the Institute of Musicology, Faculty of Arts, Masaryk University. This was personally interconnected with the resident Office of Music Lexicography. The dictionary was finally ready for printing, whilst bibliographical data and several other details were added to the new computer typeset continually up to the beginning of 1997 . During 1997 the dictionary was printed and published.

Apart from the unimaginable vast organizational and editorial activity concerning the $S \check{C} H K$ Jiři Fukač was himself author or co-author of a significant part of both historical and systematic entries (some 450 units out of the total of some 1600). In his dictionary entries that often resembled comprehensive scholarly treatises he got the chance to present his own conception of musicology. His extraordinary ability to absorb impulses, excellent memory and the gift for stylized formulation enabled Fukač to consider musicology in its full extent while conceiving his lexicographical texts. He had a good sense of orientation in all its disciplines, no matter how much his interests and potential concentrated on music historiography closely connected to music sociology and especially aesthetics (including semiotics and theory of communication). In methodology, 
he followed the tradition of Central European, especially German musicology, where Hans Heinrich Eggebrecht stood closest to him. The Office of Music Lexicography was officially directed by Jiří Vysloužil the whole time but in fact it was Jiří Fukač who was its initiator and leader since its foundation up to 1990 when he was also formally appointed head of the Office.

After the publication of $S \check{C} H K$ in 1997 Jiří Fukač soon started to work on other works of music lexicography: he actively contributed to the preparations and realization of the big lexicographical project of the Sudeten German Music Institute in Regensburg titled Lexikon zur deutschen Musikkultur (Böhmen, Mähren, Sudetenschlesien), published in Munich in 2000, where he was member of the scholarly board of the project and contributed to the conceptual and methodological preparations. He was himself author of several entries (castle bands, aesthetics, baroque era, romantic era, Josef Antonín Štěpán). There was also a previous experience of his with foreign lexicons - he wrote several entries for both latest editions of the New Grove Dictionary of Music and Musicians (1980 and 2001) as well as the entry dedicated to himself for the music encyclopaedia Die Musik in Gechichte und Gegenwart (1995).

In 2000 Jiř́i Fukač together with Petr Macek and Mikuláš Bek launched the new electronic on-line project of the Czech Music Dictionary of Persons and Institutions, he contributed to its methodology and to its glossary. He was also author of the first entries to be written. A sudden fatal illness didn't allow him to proceed any further.

Jiří Fukač was a personality that became, through both his personal destiny and scholarly work, a kind of illustration of the complex arc of development of the second half of the 20th century. He matured to a distinctive and complex personality and became a leading representative of Czech musicology and the Brno music lexicography. He respectfully resumed the work of his predecessors Gracian Černušák, Vladimír Helfert and Bohumír Štědroň and carried on developing the tradition of the Brno School of Music Lexicography. Today his pupils are happy to follow this tradition.

\section{Bibliography}

ČERNUŠÁK, Gracian. O československý hudební slovník. Hudebni rozhledy, 1953, 6, No. 4, pp. 158-159.

ČERNUŠÁK, Gracian - ŠŤĚDROŇ, Bohumír. Československý hudební slovník. Hudebni rozhledy, 1954, 7, No. 1, pp. 51-54.

FUKAČ, Jiří - VYSLOUŽIL, Jiří - MACEK, Petr. Předmluva. In Slovnik české hudebni kultury. Praha: Editio Supraphon, 1997, pp. 5-10.

FUKAČ, Jiří. Lexikografie. In FUKAČ, Jiří - VYSLOUŽIL, Jiří - MACEK, Petr (eds.). Slovnik české hudebni kultury. Praha: Editio Supraphon, 1997, pp. 495-499. 
MACEK, Petr - POLEDŇÁK, Ivan. In memoriam on the seventieth birhday of Jiří Fukač. Musicologica Brunensia, 2006, ANNUS 2003-2005, H 38-40, pp. 7-13.

MACEK, Petr. Výběrová bibliografie prací Jiřího Fukače / Selected bibliography of the work of Jiří Fukač. Musicologica Brunensia, 2006, ANNUS 2003-2005, H 38-40, pp. 15-31.

MACEK, Petr - POLEDŇÁK, Ivan. Fukač, Jiří [dictionary entry]. Český hudebni slovnik osob a instituci [online]. [cit. 2017-10-20]. URL: http://www.ceskyhudebnislovnik.cz/slovnik/index. php?option=com_mdictionary\&task=record.record_detail\&id=5234.

VYSLOUŽIL, Jiří - FUKAČ, Jiří. Nárys dokumentačního zajištění základních úkolů československé hudební lexikografie. Hudebni věda, 1968, 5, No. 2, pp. 296-305.

VYSLOUŽIL, Jiří. K tradicím a současným úkolům naší hudební lexikografie. Opus musicum, 1970, 2, No. 2, pp. 33-36, No. 3, pp. 65-69. 